\title{
TNFAIP3 Gene
}

National Cancer Institute

\section{Source}

National Cancer Institute. TNFAIP3 Gene. NCI Thesaurus. Code C84928.

This gene may play a role in the regulation of apoptosis. 